\title{
Оценка количественных характеристик опушения листьев перспективных гибридов и сортов картофеля селекции Кемеровского НИИСХ - филиала СФНЦА РАН
}

\author{
В.П. Ходаева ${ }^{1}$, В.И. Куликова ${ }^{1 *}$, О.А. Исачкова ${ }^{1}$, А.В. Дорошков ${ }^{2}$, \\ Д.А. Афонников ${ }^{2}$ \\ ${ }^{1}$ Кемеровский НИИСХ - филиал СФНЦА РАН, Кемерово, Россия \\ ${ }^{2}$ ФИЦ Институт ицитологии и генетики СО РАН, Новосибирск, Россия \\ *e-mail:kulikova.potato@yandex.ru
}

Важным фенотипическим сортовым показателем картофеля является опушение листьев, которое отвечает за формирование микроклимата у поверхности листа: чем интенсивнее опушение листа, тем выше защита растения от неблагоприятных биотических и абиотических факторов среды. Опушение у картофеля - один из факторов сопротивления растения колорадскому жуку. Растения с интенсивным опушением менее благоприятны для посещения и размножения на них тли, основного переносчика вирусных заболеваний картофеля, и демонстрируют пониженные уровни заражения вирусами $Y B K$ и $L B K$.

Исследованиями 2016-2017 гг. количественных характеристик опушения листьев перспективного гибрида картофеля 6-14-11 с использованием анализа цифровых микроизображений и обработкой изображений в компьютерной программе LHDetect2 растений in vitro (выращены в пробирках на питательной среде) и in vivo (выращены на торфяном субстрате) установлена разница между нижней (абаксиальной) и верхней (адаксиальной) стороной листа. На нижней стороне опушение плотнее, в большей степени за счет трихом малой длины - 100-300 мкм, что соответствует коротким кроющим и железистым трихомам. По результатам двухфакторного дисперсионного анализа опушения листа гибрида картофеля 6-14-11 найдено достоверное влияние на плотность опушения стороны листа $(20,13 \%)$ и среды, в которой выращено растение $(0,57 \%)$.

Анализом цифровых микроизображений выявлено, что распределение средней длины и среднего числа трихом на изображении большинства сортов картофеля варьируют в пределах 150-250 мкм, числом трихом 2-4 шт./пиксель на изображение. В то же время выделены сорта с более длинными трихомами (в среднем более 350 мкм) и с более короткими трихомами (менее 175 мкм). А также сорта с интенсивным опушением, более 5,5 шт./пиксель на изображение и слабым опушением 1,5 шт./пиксель. Исследования показали, что сорта картофеля Любава, Кузнечанка, Тулеевский относятся к числу средне опушенных соответствующих числу трихом от 2,5 до 4,0 шт./пиксель, длиной трихом от 175 до 350 мкм. Сорта Кемеровчанин, Танай имеют наиболее интенсивное опушение, число трихом 6,8 шт./пиксель и 7,3 шт./пиксель с длиной трихом 150 мкм и 200 мкм соответственно.

Как показала практика 2017 г., растения сортов картофеля Кемеровчанин, Танай с интенсивным опушением менее посещаются тлями - переносчиками вирусов картофеля. За период III декада июля - III декада августа на этих сортах в ловушках Мерике тлей не обнаружено. 